\title{
Relationship between pregnancy per artificial insemination and early luteal concentrations of progesterone and establishment of repeatability estimates for these traits in Holstein-Friesian heifers
}

\author{
M. H. Parr, ${ }^{\star} †$ M. P. Mullen, ${ }^{\star}$ M. A. Crowe,† J. F. Roche, $†$ P. Lonergan, $†$ A. C. O. Evans, $†$ and M. G. Diskin ${ }^{\star 1}$ \\ ${ }^{*}$ Animal and Grassland Research and Innovation Centre, Teagasc, Mellows Campus, Athenry, Co. Galway, Ireland \\ †School of Agriculture, Food Science and Veterinary Medicine, University College Dublin, Belfield, Dublin 4, Ireland
}

\begin{abstract}
Pregnancy per insemination is a major determinant of reproductive efficiency in cattle and is affected by concentrations of progesterone (P4) during early pregnancy. The relationship between pregnancy per artificial insemination (P/AI) and early luteal concentrations of $\mathrm{P} 4$, and repeatability of concentrations of $\mathrm{P} 4$ was examined on $\mathrm{d} 4,5,6$, and 7 (day of standing estrus $=\mathrm{d}$ 0 ) in 118 Holstein Friesian heifers following 2 rounds of AI to 1 high-fertility sire. Repeatability estimates $\left(R_{e}\right)$ for P/AI were established following 4 rounds of AI. We found a linear and quadratic relationship between $\mathrm{P} /$ $\mathrm{AI}$ and concentrations of $\mathrm{P} 4$ on d 4 to 7 after estrus, as well as a linear and quadratic relationship between $\mathrm{P} / \mathrm{AI}$ and the change in concentration of $\mathrm{P} 4$ from $\mathrm{d} 4$ to 7 and from $\mathrm{d} 5$ to 7 . Optimum concentrations of $\mathrm{P} 4$ to maximize probability of $\mathrm{P} / \mathrm{AI}$ were $2.5,4.0,5.0,5.2$, and $3.5 \mathrm{ng} / \mathrm{mL}$ for $\mathrm{d} 4,5,6$, and 7 , and the change from d 4 to 7 , respectively. Repeatability of P/AI following 4 rounds of AI was low $\left(\mathrm{R}_{\mathrm{e}}=0.07\right)$. Repeatability estimates for concentrations of $\mathrm{P} 4$ from cycle to cycle indicated low repeatability between $\mathrm{d} 4\left(\mathrm{R}_{\mathrm{e}}=0.05\right)$ and $7\left(R_{e}=0.20\right)$. These data indicated the importance of P4 in the early luteal phase for pregnancy survival, but also demonstrated that high concentrations of $\mathrm{P} 4$ on these days have a deleterious effect on embryo viability. Early luteal (d 4 to 5) concentrations of P4 were a reasonable predictor of concentrations on $\mathrm{d} 7$ and could be used as a diagnostic tool to identify animals at risk of subsequent embryo loss.
\end{abstract}

Key words: artificial insemination, progesterone, pregnancy, repeatability

\section{INTRODUCTION}

Pregnancy per insemination is a key determinant of reproductive efficiency in cattle, and improving the

Received April 29, 2011.

Accepted December 28, 2011.

${ }^{1}$ Corresponding author: Michael.Diskin@teagasc.ie rate of pregnancy per artificial insemination $(\mathbf{P} / \mathbf{A I})$ is a key objective of many research and breeding programs. The rate of $\mathrm{P} / \mathrm{AI}$ has declined by 15 to $20 \%$ as the emphasis on breeding dairy cattle shifted from the moderately yielding cows of the 1980s to the highproducing cows of the present day (Diskin et al., 2006). The majority of embryonic loss occurs by approximately d 16 following insemination (Sreenan et al., 2001). This period encapsulates a sequence of events that includes the increase in concentration of progesterone $(\mathbf{P 4})$ in the early luteal phase and a subsequent plateau during the mid-luteal phase as well as maternal recognition of pregnancy that is essential to inhibition of luteolysis.

Progesterone has long been known to play a central role in embryo development as it is involved in a cascade of molecular, biochemical, and morphological events involved in establishment and maintenance of pregnancy (Spencer et al., 2004). A delay in the increase in concentration of P4 after ovulation (Larson et al., 1997) or low concentrations of $\mathrm{P} 4$ in the early luteal phase (Diskin et al., 2006) are associated with poor pregnancy rates. Increasing concentrations of P4 support the secretory function of the uterine endometrium that sustains blastocyst development, conceptus elongation, and implantation in ruminants (Niswender et al., 2000; Spencer et al., 2004), whereas low concentrations of P4 create a suboptimal uterine environment and reduce the ability to support conceptus elongation (Forde et al., 2011). A positive relationship exists between concentration of P4 in the early luteal phase and interferon- $\tau$ synthesis (Kerbler et al., 1997) and subsequent embryo development (Mann and Lamming, 2001). The timing of the postovulatory increase in concentration of $\mathrm{P} 4$ affects the timing of the downregulation of the $\mathrm{P} 4$ receptor $\left(\mathbf{P}_{\mathbf{R}}\right)$ in the luminal and glandular epithelium, a critical event for the establishment of pregnancy to occur in all species studied (Bazer et al., 2011).

Repeatability is the coefficient of correlation between records made on the same animal in a population (Lush, 1943). Insight into the repeatability of a phenotypic trait such as $\mathrm{P} / \mathrm{AI}$ is critical for the establishment of animal models and to predict the likely response 
of selection as repeatability is the uppermost limit of heritability. There is no published literature on repeatability of P/AI in Holstein-Friesian heifers, although repeatability estimates for embryo survival have been determined for beef heifers (Diskin and Sreenan, 2005). Furthermore, little published information exists on repeatability of plasma concentrations of $\mathrm{P} 4$ on $\mathrm{d} 4$ to 7 of the estrous cycle.

Therefore, the objectives of this study were to (1) quantify the relationship between $\mathrm{P} / \mathrm{AI}$ and plasma concentrations of $\mathrm{P} 4$ on $\mathrm{d} 4,5,6$, and $7 ;$ (2) quantify the relationship between $\mathrm{P} / \mathrm{AI}$ and the change in plasma concentrations of $\mathrm{P} 4$ from d 4 to 7 ; (3) determine the concentrations of $\mathrm{P} 4$ on $\mathrm{d} 4,5,6$, and 7 necessary to maximize the probability of $\mathrm{P} / \mathrm{AI}$ in dairy heifers; (4) establish repeatability estimates $\left(\mathbf{R}_{\mathbf{e}}\right)$ for concentrations of $\mathrm{P} 4$ from cycle to cycle; and (5) establish $\mathrm{R}_{\mathrm{e}}$ for $\mathrm{P} / \mathrm{AI}$ in dairy heifers.

\section{MATERIALS AND METHODS}

\section{Animals and Management}

All experimental procedures involving heifers were licensed by the Department of Health and Children, Ireland. Protocols were in accord with the Cruelty to Animals Act (Ireland 1876, as amended by European Communities regulations 2002 and 2005) and the European Community Directive 86/609/EC and were sanctioned by the Institutional Animal Research Ethics Committee.

In total, 118 reproductively normal nulliparous Holstein-Friesian heifers from the same herd were used and were weighed and body condition scored at the start and the end of the experiment [mean \pm standard error (SE) BW of $421 \pm 6.35 \mathrm{~kg}$ and BCS of $2.9 \pm 0.04$ at the start and $584 \pm 5.93 \mathrm{~kg}$ and $3.29 \pm 0.05$ at the end]. All heifers were housed in concrete slatted pens throughout the study and had ad libitum access to grass silage with an ME of $9.9 \mathrm{MJ} / \mathrm{kg}$ of DM and a CP content of $13.2 \%$. In addition, each heifer was offered $2 \mathrm{~kg}$ of concentrates per day (10.7 MJ/kg of ME, CP 15.4\%).

\section{Estrous Synchronization}

Estrous synchronization and 4 rounds of AI were carried out during a 12-mo period, following the regimen described below, to establish the repeatability of $\mathrm{P} /$ $\mathrm{AI}$; the relationship between $\mathrm{P} / \mathrm{AI}$ and concentration of $\mathrm{P} 4$ and the repeatability of $\mathrm{P} 4$ were established in the final 2 AI rounds. Estrous cycles were synchronized by using 2 injections of a synthetic $\mathrm{PGF}_{2 \alpha}$ analog (PG, Estrumate; Intervet/Schering-Plough Animal Health, Hertfordshire, UK) administered i.m. $11 \mathrm{~d}$ apart.

\section{Estrous Detection, Al, and Determination of Pregnancy per Al}

All heifers were monitored for signs of estrus 5 times daily, beginning $2 \mathrm{~d}$ after administration of the second PG injection and continued for a further $96 \mathrm{~h}$. Estrotect heat patches (Dairymac Ltd., Hampshire, UK) were used as an aid to estrous detection. Only heifers displaying standing estrus were inseminated, by 1 of 2 experienced operators using frozen-thawed semen from 1 high-fertility bull. All AI took place within $12 \mathrm{~h}$ of standing estrus. The response to the second administration of PG varied from 90 to $95 \%$. Heifers not detected in standing estrus received a further administration of PG $11 \mathrm{~d}$ after the previous administration and were again subjected to estrous observation and AI as described above.

Pregnancy was determined by ultrasound scanning of the uterus using an Aloka SSD-500 V ultrasound scanner fitted with a $7.5-\mathrm{MHz}$ transducer (Aloka Co. Ltd., Tokyo, Japan) on d 30 following AI. A positive pregnancy diagnosis was based on the presence of an apparently viable embryo with a visible heartbeat and clear amniotic fluid. Following diagnosis, pregnancy was terminated by administration of PG to induce embryonic loss and 6 wk later (approximately 2 estrous cycles), the entire regimen was repeated. Four rounds of AI were carried out on all heifers to establish repeatability of P/AI, the final 2 rounds of which were used to estimate the relationship between $\mathrm{P} / \mathrm{AI}$ and concentration of $\mathrm{P} 4$ in the early luteal phase.

\section{Blood Sampling and Progesterone Assay}

Blood samples were collected twice daily at 0900 and $1500 \mathrm{~h}$ via jugular venipuncture on $\mathrm{d} 4,5,6$, and 7 of the final 2 rounds of AI. All blood samples were collected into 10-mL EDTA heparinized Vacutainers (Becton Dickinson Vacutainer Systems, Plymouth, UK). Samples were held in iced water until centrifugation at $1,500 \times g$ at $4^{\circ} \mathrm{C}$ for 15 min, after which plasma was extracted and stored in a $7-\mathrm{mL}$ vial at $-20^{\circ} \mathrm{C}$ until assayed.

Plasma concentrations of $\mathrm{P} 4$ were determined using the solid-phase RIA Coat-A-Count Progesterone In Vitro Diagnostic Test Kit (Siemens Medical Solutions Diagnostics, Los Angeles, CA) as previously published (Forde et al., 2011) and from which the average concentration of $\mathrm{P} 4$ was calculated to represent the particular day. The inter- and intraassay CV for samples containing $0.42,2.60$, and $7.02 \mathrm{ng}$ of $\mathrm{P} 4 / \mathrm{mL}$ were $6.3,3.52$, and $2.94 \%$ and $18.06,8.04$, and $6.77 \%$, respectively. The minimum detectable concentration of $\mathrm{P} 4$ was $0.14 \pm$ $0.08 \mathrm{ng} / \mathrm{mL}$. 
Table 1. Relationship between pregnancy per AI and concentrations of progesterone (P4), and the change $(\Delta)$ in $\mathrm{P} 4$ on $\mathrm{d} 4$ to 7 in the luteal phase in Holstein-Friesian heifers $(\mathrm{n}=236$ inseminations) presented as odds ratios (OR) with $95 \%$ CI

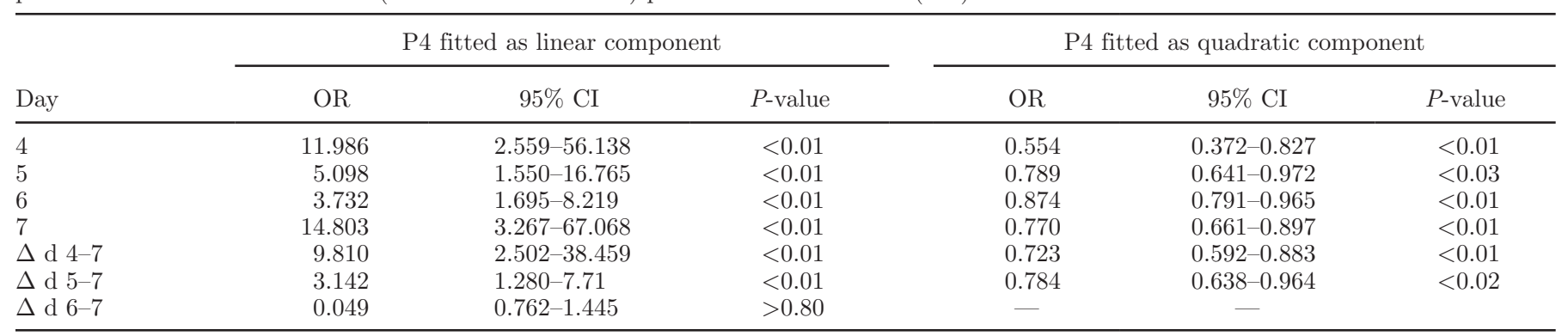

\section{Statistical Analyses}

Logistic regression analysis was undertaken using PROC GENMOD (SAS Institute, 2005) to evaluate the relationship between $\mathrm{P} / \mathrm{AI}$ and plasma concentrations of $\mathrm{P} 4$ on $\mathrm{d} 4$ to 7 post-estrus. Concentration of $\mathrm{P} 4$ was initially fitted as a linear term and where significant, concentration of $\mathrm{P} 4$ was then fitted as a quadratic term in the model. Multiple linear regression analysis was used to establish the relationship between concentrations of $\mathrm{P} 4$ on d 4, 5, and 6 to that of concentrations on d 7 . Linear and quadratic terms were included simultaneously into the model for each day examined. Repeatability estimates for P/AI were derived from an ANOVA as the intra-class correlation among records on the same heifers for all 4 rounds of AI to 1 highfertility sire. Repeatability estimates for concentrations of $\mathrm{P} 4$ from estrous cycle to cycle were derived from an ANOVA as the intra-class correlation among records on the same heifers on $\mathrm{d} 4,5,6$, and 7 , for the final 2 rounds of AI. Repeatability of $\mathrm{P} / \mathrm{AI}$ and concentrations of $\mathrm{P} 4$ from cycle to cycle were derived from the following:

$$
\mathrm{R}_{\mathrm{e}}=\frac{\sigma_{B}^{2}}{\sigma_{B}^{2}+\sigma_{W}^{2}}
$$

where $R_{e}$ is the term for repeatability, $\sigma_{B}$ is the term for between-group variation, and $\sigma_{W}$ is the term for within-group variation (Cameron, 1997).

\section{RESULTS}

\section{Relationship Between P/Al and Plasma Concentrations of P4 on $d 4$ to 7 Post-Estrus}

The relationship between $\mathrm{P} / \mathrm{AI}$ and early luteal phase concentrations of $\mathrm{P} 4$ on $\mathrm{d} 4$ to 7 is presented as odds ratios (OR) with 95\% CI in Table 1. A strong relationship was observed between $\mathrm{P} / \mathrm{AI}$ and concentrations of P4 in the early luteal phase $(P<0.01)$. We found a positive linear $(P<0.01)$ and quadratic $(P<0.01)$ association between pregnancy $\mathrm{P} / \mathrm{AI}$ and concentrations of $\mathrm{P} 4$ on $\mathrm{d} 4,5,6$, and 7 post-estrus.

On $\mathrm{d} 4,5,6$, and 7 , the concentrations of progesterone (for all 236 inseminations) were divided into quartiles, and the percentage of heifers that were pregnant in each quartile was calculated. These data along, with the probability of P/AI (derived from the logistic regression analysis), are shown in (Figure 1, a to d). Optimum P4 concentrations of 2.5, 4.0, 5.0, and $5.2 \mathrm{ng} /$ $\mathrm{mL}$ were calculated from the logistic regression curves to achieve a probability of $\mathrm{P} / \mathrm{AI}$ of $0.85,0.82,0.81$, and 0.82 on d 4, 5, 6, and 7, respectively. Pregnancy per AI increased curvilinearly as concentrations of P4 increased toward the optimum for the day but a decline was evident when concentrations of $\mathrm{P} 4$ were greater than the optimum for the day. A positive relationship $(P<0.01)$ was found between concentrations of $\mathrm{P} 4$ on $\mathrm{d} 4,5$, and 6 and the concentration of $\mathrm{P} 4$ on $\mathrm{d} 7$ (Table $2)$.

\section{Relationship Between P/Al and the Change in Concentration of P4 Between $d 4$ and 7 Post-Estrus}

A positive linear and quadratic relationship was observed between $\mathrm{P} / \mathrm{AI}$ and the change in concentrations of $\mathrm{P} 4$ between $\mathrm{d} 4$ and 7 and between d 5 and 7 (Table 1). We found no evidence of a relationship between $\mathrm{P} /$ $\mathrm{AI}$ and the change in concentration of $\mathrm{P} 4$ from $\mathrm{d} 6$ to 7. The change in concentration of $\mathrm{P} 4$ between $\mathrm{d} 4$ and 7 (for all 236 inseminations) was divided into quartiles and the percentage of heifers that were pregnant in each quartile was calculated. This data along with the probability of $\mathrm{P} / \mathrm{AI}$ (derived from the logistic regression analysis) is shown in Figure 2. An optimum change in concentration of $\mathrm{P} 4$ of $3.5 \mathrm{ng} / \mathrm{mL}$ between $\mathrm{d} 4$ and 7 was calculated from the logistic regression curve to achieve a probability of $\mathrm{P} / \mathrm{AI}$ of 0.80 . Pregnancy per AI 
a)

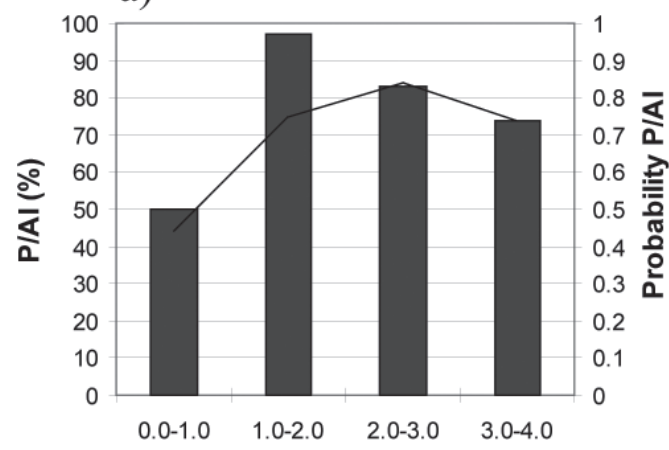

b)

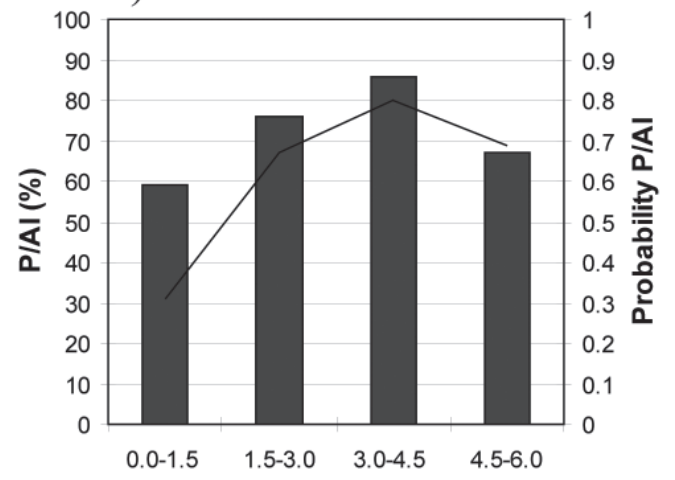

c)

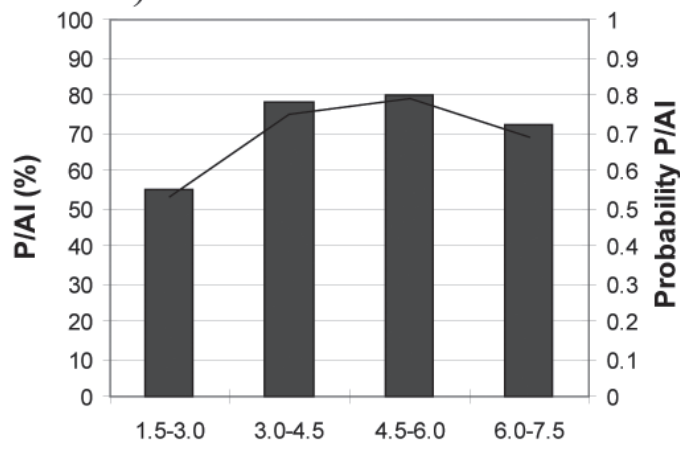

d)

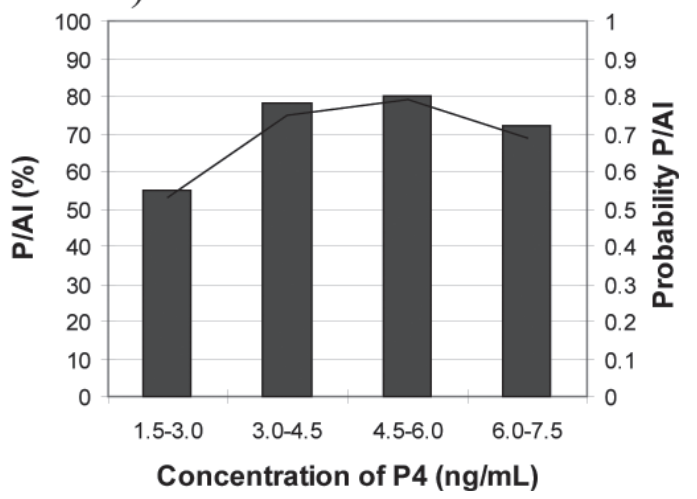

Figure 1. Percentage pregnancy per AI (P/AI; $n=236$ inseminations) in quartiles of heifers with the smallest to the greatest concentration of progesterone $(\mathrm{P} 4)$ and a logistic regression curve of the probability of P/AI on d 4 (a), d 5 (b), d 6 (c) and d 7 (d) post-estrus. increased curvilinearly as the change in concentration of $\mathrm{P} 4$ increased toward the optimum for the period but a decline in $\mathrm{P} / \mathrm{AI}$ was evident when concentrations of $\mathrm{P} 4$ were greater than the optimum.

\section{Repeatability of Concentration of P4 Between Successive Estrous Cycles}

Repeatability of concentration of $\mathrm{P} 4$ between successive estrous cycles based on repeated measurements taken from the same heifers $(\mathrm{n}=118)$ on $\mathrm{d} 4,5,6$, and 7 , following 2 different rounds of AI, ranged from $\mathrm{R}_{\mathrm{e}}=$ 0.05 to 0.20 on $\mathrm{d} 4$ to 7 , respectively.

\section{Repeatability of P/AI}

The overall $\mathrm{P} / \mathrm{AI}$ among the heifers was 70, 70, 69, and $79 \%$ and was similar $(P>0.05)$ across the 4 rounds of AI. Repeatability of P/AI was based on P/AI scores from the same heifers following 4 rounds of AI was $R_{e}$ $=0.07$. Following the 4 rounds of AI, 34 heifers became pregnant on all 4 occasions and only 2 heifers failed to become pregnant (Figure 3).

\section{DISCUSSION}

In the present study, we found a positive linear and quadratic relationship between $\mathrm{P} / \mathrm{AI}$ and concentrations of $\mathrm{P} 4$ on $\mathrm{d} 4$ to 7 following AI. When $\mathrm{P} 4$ was fitted as both a linear and quadratic term simultaneously, the relationship was curvilinear. The $\mathrm{P} / \mathrm{AI}$ increased as the concentration of $\mathrm{P} 4$ increased toward an optimum and decreased as the concentration of $\mathrm{P} 4$ surpassed the optimum. This is in agreement with previous findings in lactating dairy cows (Stronge et al., 2005; McNeill et al., 2006), beef heifers (Diskin and Sreenan, 2005), and sheep (Parr et al., 1987). In this study, where P/AI was consistently high at $>70 \%$ in heifers, the relationship between $\mathrm{P} / \mathrm{AI}$ and plasma concentrations of $\mathrm{P} 4$ during the early luteal phase following AI was identical to that observed in an earlier study with dairy cows (Stronge et al., 2005), in which a much lower P/AI rate (47\%) was achieved. The results of the current study extend the earlier results from our laboratory and confirms that the relationship between $\mathrm{P} / \mathrm{AI}$ and either plasma or milk concentration of $\mathrm{P} 4$ is very similar irrespective of the inherent level of fertility. The relationships between $\mathrm{P} / \mathrm{AI}$ and the change in concentrations in $\mathrm{P} 4$ from $\mathrm{d}$ 4 to 7 and from d 5 to 7 were also quantified. Our findings are in contrast to the study of Gorzecka et al. (2011), which found no relationship between the change in concentration of milk $\mathrm{P} 4$ in the early luteal phase in pregnant versus nonpregnant cows. 
Table 2. The relationship between concentrations of progesterone (P4) on d 4, 5, and 6 to the concentration of progesterone on $\mathrm{d} 7(\mathrm{n}=236$ inseminations)

\begin{tabular}{llcc}
\hline $\begin{array}{l}\text { Dependent } \\
\text { variable }\end{array}$ & Relationship to P4 on d 7 & $\mathrm{R}^{2}$ & $P$-value \\
\hline P4 on d 7 & $3.01+1.94(\mathrm{P} 4$ on d 4$)-0.066(\mathrm{P} 4 \text { on d } 4)^{2}$ & 0.22 & $<0.01$ \\
P4 on d 7 & $1.97+1.14(\mathrm{P} 4$ on d 5$)-0.04(\mathrm{P} 4 \text { on d } 5)^{2}$ & 0.39 & $<0.01$ \\
P4 on d 7 & $1.24+1.066(\mathrm{P} 4$ on d 6$)-0.04(\mathrm{P} 4 \text { on } 6)^{2}$ & 0.57 & $<0.01$ \\
\hline
\end{tabular}

Logistic regression analysis indicated that the optimum concentration of $\mathrm{P} 4$ to ensure the greatest probability of $\mathrm{P} / \mathrm{AI}$ was between 2.5 and $5.2 \mathrm{ng} / \mathrm{mL}$ on $\mathrm{d}$ 4 to 7 . When subdivided into quartiles of heifers with the smallest to the largest concentrations of $\mathrm{P} 4, \mathrm{P} / \mathrm{AI}$ closely followed the pattern of the logistic regression curves. Low concentrations of $\mathrm{P} 4(<1 \mathrm{ng} / \mathrm{mL})$ on $\mathrm{d}$ 6 have been shown to be detrimental to early embryo survival on d 16 (Mann and Lamming, 2001). The current study demonstrated that concentrations of $\mathrm{P} 4$ on $\mathrm{d} 4$ and 5 were a reasonable predictor of concentrations on $\mathrm{d} 7$, and thus may be useful in identifying cattle at risk of pregnancy loss because of inadequate concentrations of plasma $\mathrm{P} 4$. The potential of using $\mathrm{P} 4$ profiles in the early luteal phase to identify pregnant versus nonpregnant cows has been examined by Gorzecka et al. (2011), in which milk P4 profiles indicated $75 \%$ of true pregnant animals.

The increase in concentrations of $\mathrm{P} 4$ in the early luteal phase, at least in nonlactating cattle, was largely dependent on the amount of luteal tissue and capacity of luteal tissue to synthesize P4 (Niswender et al., 2000). Enhanced embryo development is associated with elevated concentration of $\mathrm{P} 4$ on d 4 and 5 following mating in beef heifers (Mann et al., 2003). Following

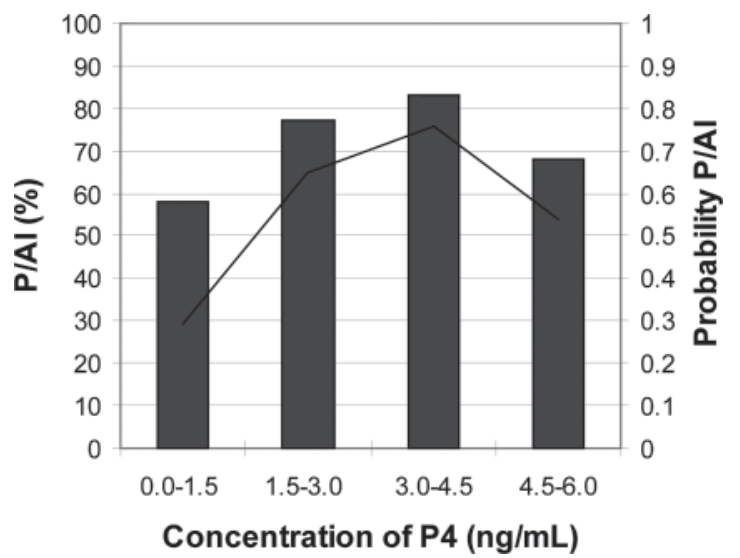

Figure 2. Percentage pregnancy per $\mathrm{AI}(\mathrm{P} / \mathrm{AI} ; \mathrm{n}=236$ inseminations) in quartiles of heifers with the smallest to the greatest change in concentration of progesterone $(\mathrm{P} 4)$ between $\mathrm{d} 4$ and 7 and a logistic regression curve of the probability of $\mathrm{P} / \mathrm{AI}$. supplementation of $\mathrm{P} 4$ in beef heifers, a positive relationship has been established between embryo survival and the change in concentration of $\mathrm{P} 4$ between $\mathrm{d} 3$ and 6.5 (Beltman et al., 2009). In the study of Starbuck et al. (2001), a significant increase in P/AI was achieved as a result of selective exogenous $\mathrm{P} 4$ supplementation to cows with low milk P4 (1-2 ng/mL) on d 5. Concentration of $\mathrm{P} 4$ in the early luteal phase does not affect the ability of the embryo to reach the blastocyst stage, but optimum concentrations are required for elongation posthatching (Clemente et al., 2009; Carter et al., 2010). We found evidence in this study of a decline in $\mathrm{P} / \mathrm{AI}$ when concentrations of $\mathrm{P} 4$ exceeded the optimum level calculated for the day. This would indicate that supplementation of exogenous P4 to cattle with already adequate concentrations of $\mathrm{P} 4$ in the early luteal phase may cause pregnancy loss. This loss may be due to the premature downregulation of the $\mathrm{P}_{\mathrm{R}}$ due to continuous exposure of the endometrial epithelium to elevated $\mathrm{P} 4$ (Okumu et al., 2010). The timing of the downregulation of the $\mathrm{P}_{\mathrm{R}}$ is a key event for the occurrence of maternal recognition of pregnancy (Bazer et al., 2011.

Repeatability is the upper limit of heritability and is an important determinant of the potential rate of genetic improvement in the dairy herd. Repeatability estimates calculated for early luteal phase concentrations of $\mathrm{P} 4$ were low and varied from $\mathrm{R}_{\mathrm{e}}=0.05$ to 0.20 on $\mathrm{d} 4$ to 7 , respectively. This is the first study to determine repeatability estimates for plasma concentration of $\mathrm{P} 4$ on $\mathrm{d} 4$ to 7 of the estrous cycle. Our findings were largely in agreement with those of Reed et al. (1985), who found a somewhat lower repeatability estimate of $\mathrm{R}_{\mathrm{e}}=0.115$ for blood serum P4 on $\mathrm{d} 7$ in Holstein and crossbred dairy heifers.

In addition, this is the first comprehensive report to determine a repeatability estimate for $\mathrm{P} / \mathrm{AI}$ in Holstein-Friesian heifers. The estimate obtained here $\left(R_{e}=0.07\right)$ was somewhat lower than that obtained in beef heifers $\left(R_{e}=0.18\right.$; Diskin and Sreenan, 2005), but similar to that obtained in sheep $\left(\mathrm{R}_{\mathrm{e}}=0.07\right.$; Hanrahan, 1982). Although this estimate was based on the genetic makeup of 118 heifers, it is in line with repeatability estimates for other key fertility traits, such as days to first service and gestation length, in cattle (Toghiani Pozveh et al., 2009). 


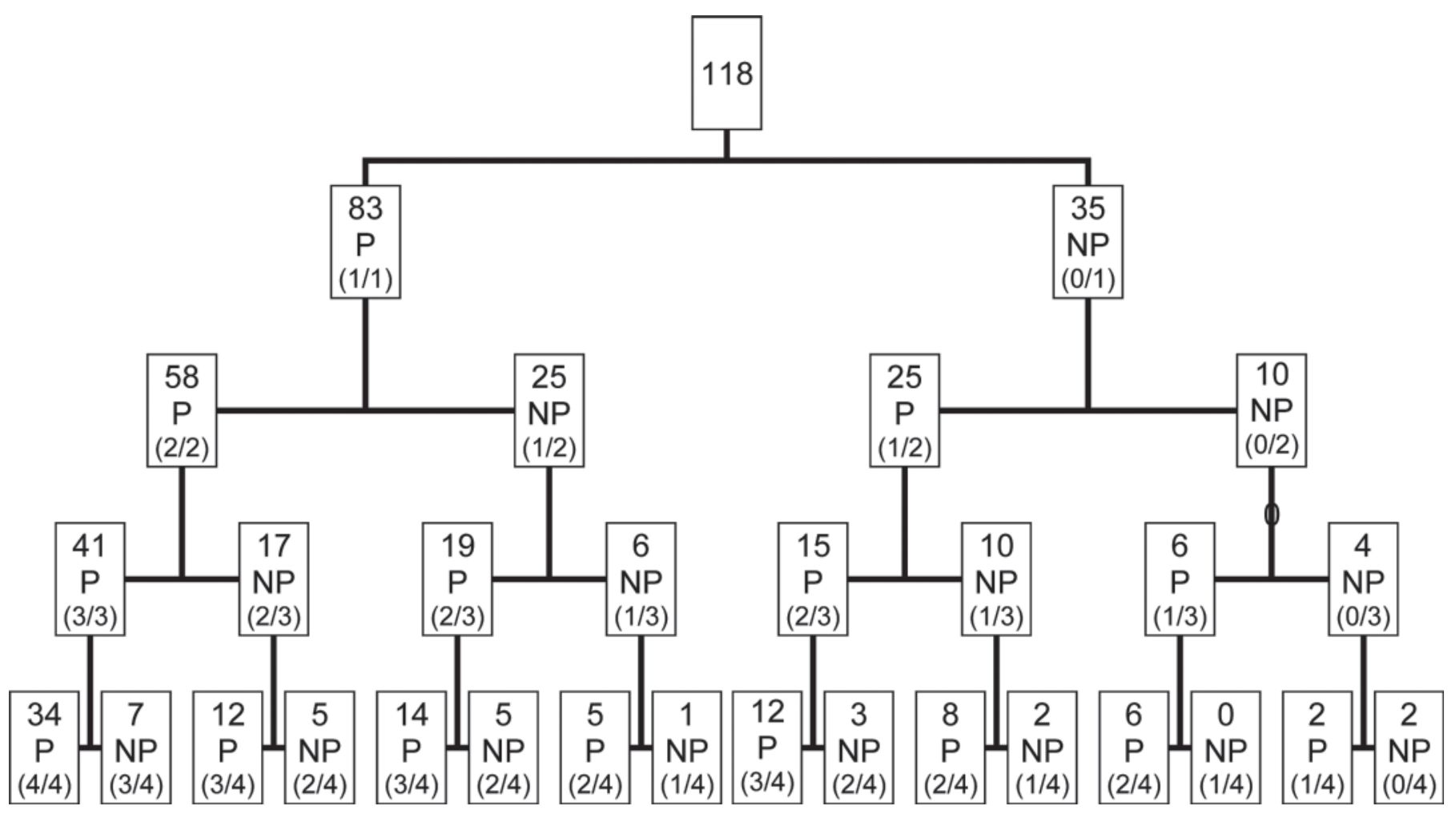

Figure 3. Breakdown of pregnancy per AI $(\mathrm{P} / \mathrm{AI})$ in Holstein-Friesian heifers $(\mathrm{n}=118)$ following 4 inseminations. $\mathrm{P}=$ pregnant; $\mathrm{NP}=$ not pregnant; the $\mathrm{P} / \mathrm{AI}$ score is given in parentheses indicating number of times pregnant per number of inseminations.

In conclusion, the relationships between $\mathrm{P} / \mathrm{AI}$ and early luteal concentrations of $\mathrm{P} 4$ were quantified in dairy heifers. This study clearly indicated that, with optimum concentrations of $\mathrm{P} 4$ during the early luteal phase, $\mathrm{P} / \mathrm{AI}$ of at least $70 \%$ was achieved in this group of heifers. Repeatability estimates for P/AI and early luteal phase concentrations of $\mathrm{P} 4$ were low in dairy heifers; thus, we conclude that little genetic improvement can be achieved by including these traits as part of a selection index for replacements in the dairy herd. Overall, measurement of plasma concentrations of $\mathrm{P} 4$ in the early luteal phase may have the potential to be used as a diagnostic tool to identify animals at risk of pregnancy loss and further improve reproductive efficiency in dairy cattle.

\section{ACKNOWLEDGMENTS}

We thank A. Glynn for her invaluable assistance with progesterone assays. We also thank P. Joyce and W. Connolly for technical assistance and G. Burke and F. Burke (all of the Animal and Grassland Research and Innovation Centre, Teagasc, Athenry, Co. Galway, Ireland) for care of the animals. The project was funded by Science Foundation Ireland (07/SRC/B1156).

\section{REFERENCES}

Bazer, F. W., T. E. Spencer, G. A. Johnson, and R. C. Burghardt. 2011. Uterine receptivity to implantation of blastocysts in mammals. Front. Biosci. (Schol. Ed.) 3:745-767.

Beltman, M. E., P. Lonergan, M. G. Diskin, J. F. Roche, and M. A. Crowe. 2009. Effect of progesterone supplementation in the first week post conception on embryo survival in beef heifers. Theriogenology 71:1173-1179.

Cameron, N. D. 1997. Selection Indices and Prediction of Genetic Merit in Animal Breeding. CAB International, Wallingford, UK.

Carter, F., F. Rings, S. Mamo, M. Holker, A. Kuzmany, U. Besenfelder, V. Havlicek, J. P. Mehta, D. Tesfaye, K. Schellander, and P. Lonergan. 2010. Effect of elevated circulating progesterone concentration on bovine blastocyst development and global transcriptome following endoscopic transfer of in vitro produced embryos to the bovine oviduct. Biol. Reprod. 83:707-719.

Clemente, M., J. de La Fuente, T. Fair, A. Al Naib, A. Gutierrez-Adan, J. F. Roche, D. Rizos, and P. Lonergan. 2009. Progesterone and conceptus elongation in cattle: A direct effect on the embryo or an indirect effect via the endometrium? Reproduction 138:507-517.

Diskin, M. G., J. J. Murphy, and J. M. Sreenan. 2006. Embryo survival in dairy cows managed under pastoral conditions. Anim. Reprod. Sci. 96:297-311.

Diskin, M. G., and J. M. Sreenan. 2005. Repeatability of embryo survival in beef heifers. J. Anim. Sci. 83(Suppl. 1):38. (Abstr.)

Forde, N., M. E. Beltman, G. B. Duffy, P. Duffy, J. P. Mehta, P. Ó'Gaora, J. F. Roche, P. Lonergan, and M. A. Crowe. 2011. Changes in the endometrial transcriptome during the bovine estrous cycle: Effect of low circulating progesterone and consequences for conceptus elongation. Biol. Reprod. 84:266-278.

Gorzecka, J., M. C. Codrea, N. C. Friggens, and H. Callesen. 2011. Progesterone profiles around the time of insemination do not show 
clear differences between of pregnant and not pregnant dairy cows. Anim. Reprod. Sci. 123:14-22.

Hanrahan, J. P. 1982. Selection for increased ovulation rate, litter size and embryo survival. Pages 294-309 in Proc. 2nd World Congr. Genet. Appl. Livest. Prod. Editorial Garsi, Madrid, Spain.

Kerbler, T. L., M. M. Buhr, L. T. Jordan, K. E. Leslie, and J. S. Walton. 1997. Relationship between maternal plasma progesterone concentration and interferon-tau synthesis by the conceptus in cattle. Theriogenology 47:703-714.

Larson, S. F., W. R. Butler, and W. B. Currie. 1997. Reduced fertility associated with low progesterone postbreeding and increased milk urea nitrogen in lactating cows. J. Dairy Sci. 80:1288-1295.

Lush, J. L. 1943. Animal Breeding Plans. Collegiate Press, Ames, IA.

Mann, G. E., M. P. Green, K. D. Sinclair, K. J. Demmers, M. D. Fray, C. G. Gutierrez, P. C. Garnsworthy, and R. Webb. 2003. Effects of circulating progesterone and insulin on early embryo development in beef heifers. Anim. Reprod. Sci. 79:71-79.

Mann, G. E., and G. E. Lamming. 2001. Relationship between maternal endocrine environment, early embryo development and inhibition of the luteolytic mechanism in cows. Reproduction 121:175-180

McNeill, R. E., M. G. Diskin, J. M. Sreenan, and D. G. Morris. 2006 Associations between milk progesterone concentration on different days and with embryo survival during the early luteal phase in dairy cows. Theriogenology 65:1435-1441.

Niswender, G. D., J. L. Juengel, P. J. Silva, M. K. Rollyson, and E. W. McIntush. 2000. Mechanisms controlling the function and life span of the corpus luteum. Physiol. Rev. 80:1-29.

Okumu, L. A., N. Forde, A. G. Fahey, E. Fitzpatrick, J. F. Roche, M. A. Crowe, and P. Lonergan. 2010. The effect of elevated progesterone and pregnancy status on mRNA expression and localisation of progesterone and oestrogen receptors in the bovine uterus. Reproduction 140:143-153.
Parr, R. A., I. F. Davis, R. J. Fairclough, and M. A. Miles. 1987. Overfeeding during early pregnancy reduces peripheral progesterone concentration and pregnancy rate in sheep. J. Reprod. Fertil. $80: 317-320$

Reed, M. L., J. D. Roussel, and S. H. Seybt. 1985. Repeatability of blood serum progesterone levels in dairy heifers on day 7 of the estrous cycle. Theriogenology 24:643-646.

SAS Institute. 2005. Users Guide: Statistics. Version 9.1. SAS Institute Inc., Cary, NC.

Spencer, T. E., G. A. Johnson, R. C. Burghardt, and F. W. Bazer. 2004. Progesterone and placental hormone actions on the uterus: Insights from domestic animals. Biol. Reprod. 71:2-10.

Sreenan, J. M., M. G. Diskin, and D. G. Morris. 2001. Embryo survival rate in dairy cattle: A major limitation to the achievement of high fertility. Pages 93-104 in Proceedings of the Fertility in the HighProducing Dairy Cow. Br. Soc. Anim. Sci. Occ. Publ. Br. Soc. Anim. Sci., Edinburgh, UK.

Starbuck, G. R., A. O. Darwash, G. E. Mann, and G. E. Lamming. 2001. The detection and treatment of post insemination progesterone insufficiency in dairy cows. Pages 447-450 in Proceedings of the Fertility in the High-Producing Dairy Cow. Br. Soc. Anim. Sci. Occ. Publ. Br. Soc. Anim. Sci., Edinburgh, UK

Stronge, A. J. H., J. M. Sreenan, M. G. Diskin, J. F. Mee, D. A. Kenny, and D. G. Morris. 2005. Post-insemination milk progesterone concentration and embryo survival in dairy cows. Theriogenology 64:1212-1224

Toghiani Pozveh, S., A. A. Shadparvar, M. Moradi Shahrbabak, and M. D. Taromsari. 2009. Genetic analysis of reproduction traits and their relationship with conformation traits in Holstein cows. Livest. Sci. 125:84-87. 